\title{
WNIOSKI I POSTULATY (NIE TYLKO) DE LEGE FERENDA W OBLICZU KRYZYSU W WYBORACH SAMORZĄDOWYCH 2014 ROKU
}

\section{Wstęp}

Zarządzone na dzień 16 listopada 2014 r. wybory do organów jednostek samorządu terytorialnego w Polsce zakończyły się bezprecedensowym w skali III RP kryzysem wyborczym. Awaria systemu wspomagania informatycznego wyborów uniemożliwiła większości terytorialnych (gminnych, miejskich, powiatowych i wojewódzkich) komisji wyborczych (TKW) sprawne zebranie, od podległych im miejscowo obwodowych komisji wyborczych (OKW), wyników głosowania, a w konsekwencji ustalenie na swoim obszarze wyników głosowania i wyborów radnych do rad gmin, miast, powiatów i sejmików województw. Jak informowała na swoich kolejnych konferencjach prasowych Państwowa Komisja Wyborcza $(\mathrm{PKW}),{ }^{1} \mathrm{w}$ trakcie ustalanie wyników wyborów generowane $\mathrm{z}$ systemu informatycznego protokoły zawierały błędy, a część komisji terytorialnych, ze względu na niesprawność systemu, nie mogła ani zweryfikować poprawności danych spływających z obwodów, ani dokonać podziału mandatów, ani nawet wydrukować protokołów z wyborów. W tym czasie media, szeroko relacjonujące sprawę problemów informatycznych, donosiły o przekłamaniach w protokołach wyborczych czy wręcz zafałszowanych wynikach wyborów. ${ }^{2} \mathrm{~W}$ efekcie ustalenie wyników głosowania i wyborów na obszarze wielu jednostek odbyło się bez użycia dedykowanego wspomagania informatycznego, ale w oparciu o tradycyjne rozwiązania z wykorzystaniem arkuszy kalkulacyjnych czy po prostu zwykłych kalkulatorów. W oczywi-

1 Zapis wideo z tych konferencji jest dostępny na oficjalnym kanale PKW w serwisie YouTube. Zob. https://www. youtube.com/channel/UC0QkQmdh1jSuntKardYq-Tw (data dostępu: 30.12.2014 r.).

2 Media podały m.in., że w Szczecinie Krzysztof Woźniak został zwycięzcą w wyborach na prezydenta tego miasta, mimo że kandydował, ale w innej gminie. Zob. W Szczecinie wygrał kandydat, którego nie było; http://wiadomosci.wp.pl/kat,1342,title,W-Szczecinie-wygral-kandydat-ktorego-nie-bylo,wid,17043603, wiadomosc.html (data dostępu: 30.12.2014 r.). 
sty sposób wpłynęło to na przedłużenie pracy członków komisji wyborczych, które w sytuacji dużego nacisku ze strony mediów i polityków, pozbawionych sprawnych narzędzi wspomagających proces ustalania wyników wyborów działały w bardzo niekorzystnych warunkach, co tylko zwiększało prawdopodobieństwo kolejnych błędów i pomyłek, a zwrotnie potęgowało jeszcze obraz kryzysu.

Sprawy nie ułatwiła też postawa Państwowej Komisji Wyborczej i obsługującego ją aparatu urzędniczego w postaci centrali Krajowego Biura Wyborczego (KBW), które w obliczu oczywistego kryzysu informatycznego nie potrafiły na czas zareagować, zwlekały z wydaniem nowych dyrektyw dla komisji wyborczych, do końca informowały opinię publiczną, że system informatyczny jest poprawiany i lada moment uzyska pełną sprawność, ${ }^{3}$ a w konsekwencji nie potrafiły zarządzać sytuacją kryzysową ani w wymiarze organizacyjnym, ani komunikacyjnym. Wszystko to wpłynęło tylko na pogłębienie obrazu kryzysu w oczach opinii publicznej oraz rozpoczęło falę bardzo ostrej, nie zawsze do końca merytorycznie uzasadnionej, krytyki wobec KBW, a zwłaszcza PKW. W efekcie cały skład Komisji ${ }^{4}$ razem z jej sekretarzem, będącym jednocześnie z mocy ustawy szefem KBW, podali się do dymisji z dniem 1 grudnia $2014 \mathrm{r}$. Nie rozwiązało to jednak, bo rozwiązać nie mogło, niesprawności organizacyjno-komunikacyjnej centralnego aparatu wyborczego ujawnionej $\mathrm{w}$ toku wyborów samorządowych. Kwestia ta jest o tyle istotna, że w 2015 r. w Polsce odbywają się kolejne dwie elekcje, prezydenckie i parlamentarne. Budzą one dużo większe zainteresowanie i siłą rzeczy są znacznie ważniejsze politycznie, gdyż decydują o przyszłej władzy i kierunkach polityki państwa na najbliższe lata. To właśnie te wybory przesądzają o kluczowej z punktu widzenia demokratycznego państwa prawa, legitymizacji władzy politycznej. Tymczasem awaria systemu informatycznego, niesprawność organizacyjna i niedecyzyjność KBW oraz błędy w obszarze polityki komunikacyjnej i nadzorczej ze strony PKW, doprowadziły do podkopania zaufania polityków, mediów oraz obywateli do organów wyborczych i szerzej samych procedur wyborczych. W reprezentatywnym sondażu opinii publicznej przeprowadzonym przez CBOS po zakończeniu II tury wyborów samorządowych działalność PKW skrytykowało aż dwie trzecie Polaków (63\% badanych), natomiast tylko ponad jedna piąta (22\%) wypowiadała się o niej pozytywnie. Mimo że we wszystkich analizowanych przez CBOS grupach społecznych przeważały osoby negatywnie odbierające pracę PKW, to jednak największy odsetek zanotowano wśród osób o najwyższym statusie społecznym. Bardzo krytycznie działalność PKW oceniło 76\% osób z wyższym wykształceniem, 77\% kadry kierowniczej i specjalistów, 70\% osób o dochodzie powyżej 1500 zł na osobę w ro-

Przykładowo na konferencji prasowej w dniu 17 listopada 2014 r. o godz. 22.00 sędzia Stanisław Zabłocki twierdził, że wedle przekazanych mu informacji, segment systemu informatycznego odpowiedzialny za wydruk protokołów w wyborach na wójtów, burmistrzów i prezydentów już działa prawidłowo. Natomiast nadal niesprawny moduł wykorzystywany w wyborach proporcjonalnych do rad miał taką sprawność uzyskać w ciągu kilku godzin. Wyjątkiem był sędzia Sądu Najwyższego Wiesław Kozielewicz powołany decyzją prezydenta z dniem 21 listopada w miejsce Stanisława Kosmali, którego członkostwo wygasło w związku z ukończeniem 70. roku życia. 
Wnioski i postulaty (nie tylko) de lege ferenda w obliczu kryzysu w wyborach...

dzinie i 69\% pracowników instytucji publicznych. ${ }^{5}$ Oznacza to spektakularny krach zaufania Polaków do organów wyborczych, co jest o tyle dramatyczne, że jak do tej pory cieszyły się one niezmiennie wysoką estymą, zaufaniem oraz opinią administracji niezależnej i profesjonalnej.

Mimo ogólnopolskiej dyskusji, która rozpoczęła się w zasadzie już nazajutrz po wyborach, na temat reformy prawa i instytucji wyborczych w Polsce, do tej pory nie pojawiła się ani naukowa analiza przyczyn kryzysu, ani tym bardziej spójna i adekwatna do zaistniałego problemu wizja niezbędnych zmian. ${ }^{6}$ Niestety większość propozycji, które w ciągu pierwszych tygodni po wyborach funkcjonowały w otoczeniu medialno-politycznym, nie miała charakteru kompleksowego, nadmiernie skupiała się na warstwie kodeksowej, a często była po prostu nietrafiona czy wręcz politycznie uwarunkowana. Tymczasem diagnoza musi poprzedzać leczenie, a nie odwrotnie. Przygotowanie jakiegokolwiek planu naprawczego wymaga w pierwszej kolejności zidentyfikowania przyczyn zaistniałej sytuacji oraz sformułowania szczegółowej analizy problemu. W ten sposób możliwe będzie określenie nie tylko obszarów niezbędnych zmian, ale również zaproponowanie konkretnych propozycji działań reformatorskich. Zasadniczym celem tego artykułu jest podjęcie próby realizacji tego postulatu.

\section{Złe zarządzanie projektem wdrożenia systemu informatycznego}

Bezpośrednią przyczyną kryzysu była awaria informatycznego systemu wspomagania wyborów, a dokładniej rzecz ujmując systemu obsługi komisji wyborczych ustalających wyniki głosowania i wyniki wyborów o nazwie „Platforma wyborcza”. Jedną z najważniejszych funkcji tego systemu miało być umożliwienie obwodowym komisjom wyborczym wprowadzenia i weryfikacja, pod względem poprawności arytmetycznej, ustalonych przez komisję podczas liczenia kart wyborczych wyników głosowania, a następnie sporządzenie protokołów głosowania (wydrukowanie papierowej jego wersji) w obwodzie i przekazanie wyników do systemu centralnego (przesłanie danych elektronicznie), z którego korzystać miały komisje wyższego szczebla. Na tej podstawie TKW powinny z kolei przeprowadzić weryfikację prawidłowości ustalenia wyników głosowania przez OKW, dokonać ustalenia zbiorczych wyników głosowania (arytmetyczna agregacja głosów ustalonych w podległych

Zob. M. Feliksiak, Opinie o działalności parlamentu, prezydenta i PKW, „Komunikat z Badań CBOS” 2014, nr 169, s. 4 in.

6 Do czasu ukończenia prac nad tym artykułem (tj. do 15 stycznia 2015 r.) nie było żadnej kompleksowej analizy przyczyn zaistniałego kryzysu. Taka analiza (dotycząca jednak tylko przebiegu procesu informatyzacji wyborów) pojawiła się w dniu 31 marca 2015 r., kiedy to Najwyższa Izba Kontroli skierowała do Krajowego Biura Wyborczego wystąpienie pokontrolne dotyczące wykorzystania środków z budżetu państwa na obsługę informatyczną wyborów samorządowych w roku 2014. Ustalenia pokontrolne sformułowane przez NIK praktycznie w całości potwierdziły wnioski, do jakich doszedł autor tego artykułu na podstawie samodzielnie przeprowadzonej analizy. 
im komisjach obwodowych) i przede wszystkim wyborów (czyli przeprowadzić transformacje głosów w mandaty) na obszarze odpowiednio gminy (gminne komisje wyborcze), miasta (miejskie komisje wyborcze), powiatu (powiatowe komisje wyborcze), województwa (wojewódzkie komisje wyborcze). Z kolei kontroli prawidłowości ustaleń TKW mieli dokonać właściwi miejscowo komisarze wyborczy działający na podległym im obszarze jako pełnomocnicy PKW.7 Podkreślić w tym miejscu należy, że system ten nie służył, i nigdy jako taki nie był planowany, jako narzędzie elektronicznego liczenia głosów. Te bowiem były i są w Polsce cały czas liczone ręcznie przez członków OKW. Rolą systemu było natomiast wyeliminowanie ewentualnych błędów rachunkowych komisji, sporządzenie poprawnych wydruków protokołów z głosowania i wyborów oraz przesłanie ich do systemu centralnego.

Mimo pewnych trudności i błędów w generowaniu protokołów głosowania, system informatyczny na szczeblu OKW zasadniczo zadziałał. Problemy pojawiły się natomiast od poziomu TKW, gdzie ze względu na błędy i przekłamania w wydrukach formularzy (najpierw nie można było ich wydrukować) nie sposób było dokonać podziału mandatów pomiędzy komitety wyborcze w wyborach proporcjonalnych. W rezultacie TKW nie mogły ogłosić pełnych wyników wyborów. Nie mając protokołów z TKW, analogicznej weryfikacji i podania zbiorczych wyników wyborów nie mogli dokonać wojewódzcy komisarze wyborczy (dla obszaru województwa) oraz PKW (dla obszaru państwa). Oczekiwanie na przywrócenie pełnej sprawności systemu, który do końca takiej sprawności i tak nie uzyskał, oraz brak przygotowania przez KBW alternatywnych narzędzi wspomagających ustalenie i weryfikację wyników wyborów, doprowadziło do sytuacji, w której zdezorientowane komisje terytorialne traciły czas, a ostatecznie zmuszone były przeprowadzić procedurę weryfikacji, sumowania i podziału mandatów w oparciu o naprędce przygotowane, często tylko we własnym zakresie, tradycyjne narzędzia, jak arkusz kalkulacyjny, kalkulatory itp. W efekcie proces ustalania i ogłaszania wyników wyborów w całym kraju trwał tydzień.

Wielu krytyków PKW i KBW główną przyczynę tej awarii upatrywało w wykonawcy, twierdząc, że była to firma bez należytego doświadczenia, o za słabym potencjale kadrowym, zatrudniająca studentów, a kryterium rozstrzygającym o jej zwycięstwie była niska cena. Zarzucano również błędy w specyfikacji zamówienia i samej procedurze przetargowej. Nie dokonując w tym miejscu oceny ani informatycznych możliwości tej firmy, ani formalnych warunków przeprowadzenia przetargu, należy jednak zauważyć, że dokonana przez KBW specyfikacja istotnych warunków zamówienia na system informatyczny cenie przyznawała znaczenie tylko na poziomie $49 \%$, reszta punktów miała być przyznana za przygotowanie wstępnych projektów dwóch modułów systemu, w tym najważniejszego, tj. kalkulatora wybor- 
czego dla OKW. ${ }^{8}$ Co więcej, moduł ten zasadniczo w dniu głosowania zadziałał. To, co przesądziło o awarii, to zbyt mało czasu na wykonanie całego systemu (przetarg rozstrzygnięto dopiero 4 sierpnia 2014 r. ${ }^{9}$ ) i przede wszystkim na jego poprodukcyjną ewaluację dokonaną przed wyborami, najpierw przez wewnętrznych testerów, a później docelowych użytkowników. Błąd zlokalizowany był więc po stronie zarządzania wdrożeniem projektu informatycznego i to już na samym jego początku. Skupiając się na warstwie formalnej przetargów, KBW pominęło całkowicie sferę faktycznego planowania. Nie przeprowadzono poważnej analizy ryzyk w projekcie, nie skonsultowano $\mathrm{z}$ delegaturami w terenie i końcowymi użytkownikami ani założeń systemu, ani nawet harmonogramu jego realizacji, nie przygotowano żadnego planu awaryjnego i narzędzi zastępczych. Projekt wdrożenia informatycznego był źle koordynowany i nadzorowany. Zgłaszane w trakcie jego wdrożenia uwagi z terenu nie zawsze były brane pod uwagę, a usterki naprawiane, zapewne ze względu na braki czasowe i kadrowe. Wykonawca otrzymał też zbyt późno pewne kluczowe dane, a wydruki protokołów nie zostały poddane audytowi wcale. ${ }^{10}$

Co zrobić, by uniknąć takich sytuacji w przyszłości? Przede wszystkim należy profesjonalnie podejść do zarządzania projektem samego wdrożenia informatycznego. Należałoby dokonać dokładnego przeglądu zasobów informatycznych KBW (sprzęt, oprogramowanie, ludzie, zarządzanie), stworzyć zajmujący się tylko tym zespół projektowy, w razie konieczności także przy wykorzystaniu ekspertów i instytucji zewnętrznych, np. w ramach dialogu technicznego (właściwe organy państwa, placówki naukowo-badawcze, Polska Izba Informatyki i Telekomunikacji, firmy z branży informatycznej itp.), który opracowałby, przy aktywnym udziale użytkowników końcowych tego systemu (przede wszystkim delegatur terenowych KBW oraz informatyków w komisjach wyborczych), merytoryczno-informatyczne założenia całościowego (a więc nie tylko na potrzeby jednej akcji wyborczej) systemu informatyki wyborczej. W dalszej kolejności zespół ten powinien przygotować niezbędną specyfikację przetargową, wyłonić wykonawcę, zarządzać projektem wdrożenia tego systemu (zgodnie z metodykami zarządzania projektami, jak np. PRINCE2, opracowanymi właśnie na potrzeby realizacji takich złożonych zadań),

Zob. Specyfikacja istotnych warunków zamówienia na „Zaprojektowanie i wykonanie modułów do wyborów samorządowych 2014 r. wraz administrowaniem i utrzymaniem” z dnia 11 lipca 2014 r. (KBW ZP-3710-16/14), punkt XII, s. 6; http://pkw.gov.pl/zamowienia-publiczne/zaprojektowanie-i-wykonanie-modulow-do-wyborow-samorzadowych-2014 r.-wraz-z-administrowaniem-i-utrzymaniem.html (data dostępu: 30.12 .2014 r.).

Zob. Ogłoszenie o wyniku postępowania na „Zaprojektowanie i wykonanie modułów do wyborów samorządowych 2014 r. wraz z administrowaniem i utrzymaniem" z dnia 4 sierpnia 2014 r. (KBW ZP-3710-16/14), http://pkw. gov.pl/zamowienia-publiczne/zaprojektowanie-i-wykonanie-modulow-do-wyborow-samorzadowych-2014r.-wraz-z-administrowaniem-i-utrzymaniem.html (data dostępu: 30.12 .2014 r.).

10 Maciej Cetler, wiceprezes firmy Nabino, która współtworzyła system do obsługi wyborów, tłumaczył się dziennikarzom, że „niezbędne do wykonania oprogramowania informacje o tym, do jakich organów samorządu (np. rady Warszawy, sejmiku województwa mazowieckiego) odbędą się wybory w danym obwodzie, Nabino otrzymało dopiero 15 października”. Dodał, że dopiero od tego terminu firma mogła przeprowadzać rzetelne testy w zakresie obliczania wyników wyborów. Zob. Przestrogi Nabino. Wyjaśnienia firmy współtworzącej system do obsługi wyborów; http://samorzad.pap.pl/depesza/szablon.depesza/dep/146232/ (data dostępu: 30.12.2014 r.). 
koordynować integrację tego systemu, dokonywać bieżącej ewaluacji i odpowiednio reagować na pojawiające się nieprawidłowości.

\section{Brak wewnętrznej „,refleksji systemowej”}

Plan awaryjny jest ważnym elementem planowania $\mathrm{w}$ każdej organizacji na wypadek nieprzewidzianych sytuacji. Jest to jeden $\mathrm{z}$ fundamentów współczesnego zarządzania. Decydenci muszą rozumieć, że im bardziej złożona organizacja i dynamiczne otoczenie, tym większa potrzeba przygotowywania tego typu planów, gdyż rośnie prawdopodobieństwo wystąpienia zdarzeń nieoczekiwanych. Plan taki musi więc określić alternatywne sposoby dziania na wypadek, gdyby właściwy plan został nieoczekiwanie zakłócony lub przestał być odpowiedni w zmienionych warunkach. ${ }^{11}$ Analizując ujawnione, dzięki posłowi Przemysławowi Wiplerowi, ${ }^{12}$ protokoły z posiedzeń PKW w 2014 r. widać, że nikt poważnie nie brał pod uwage sytuacji, w której wybory mogłyby się odbyć bez wspomagania informatycznego, mimo że pojawiały się już pierwsze poważne sygnały o nieprawidłowościach. Co więcej, wywołały one uzasadnione obawy niektórych członków Komisji. Jest to niewątpliwie błąd nadzorczy, błąd jednak nie sytuacyjny. Podobne problemy koordynacyjne i informatyczne (choć na mniejszą skalę i ze względu na zapasy czasowe rozwiązywane na bieżąco) występowały już w przeszłości. Miejsca pojawienia się ewentualnego kryzysu można było zatem zidentyfikować, gdyby wcześniej poważnie przeanalizowano pojawiające się co wybory nieprawidłowości w organizacji procesu wspomagania informatycznego, takie jak: niewłaściwa koordynacja między integratorem systemu, jakim było KBW a wykonawcami systemu, niedotrzymywanie harmonogramów wdrożenia informatycznego, brak audytów oprogramowania, niereagowanie lub bagatelizowanie przez centrum decyzyjne problemów sygnalizowanych przez terenowe delegatury KBW itd.

Mamy więc w tym przypadku do czynienia z poważnym błędem natury ogólnej dotyczącym tego, co używając języka teorii systemów można określić mianem „braku wewnętrznej refleksyjności”. Refleksyjność ta, w opisywanym przypadku, powinna przybrać formę stałej, obiektywnej i profesjonalnej analizy zarówno samych procesów wyborczych zarządzanych przez KBW i nadzorowanych przez PKW, jak i sposobów działania i reagowania obydwu instytucji na zmieniającą się sytuację. Brak zarówno bieżącej, jak i systemowej ewaluacji stosowanych procedur wyborczych doprowadził do sytuacji, w której w obliczu wybuchu kryzysu informatycznego właściwi decydenci nie mieli wystarczających informacji umożliwiających im adekwatne i szybkie reagowanie zarówno na zaistniałą sytuację kryzysową, jak

R.W. Griffin, Podstawy zarządzania organizacjami, wyd. 2, Warszawa 2004, s. 223-224.

12 Zob. Ujawniamy protokoły PKW z 2014 roku; http://www.wipler.pl/2014/11/ujawniamy-protokoly-pkw-z-2014-roku/ (data dostępu: $30.12 .2014 \mathrm{r}$.). 
Wnioski i postulaty (nie tylko) de lege ferenda w obliczu kryzysu w wyborach...

i na podejmowanie działań mających na celu długofalową optymalizację zarządzania procesami wyborczymi.

By takim sytuacjom zaradzić w przyszłości, konieczne jest wypracowanie stałych procedur służących do ewaluacji i wewnętrznego audytu organizacji. Chodzi zarówno o analizę „oprzyrządowania” prawnego i informatycznego administracji wyborczej, ale również samej instytucji, dostosowania jej struktury i zatrudnienia do bieżących zadań, identyfikowania systemowych „wąskich gardeł” w procesie wyborczym oraz przede wszystkim analizy organizacyjnej poszczególnych akcji wyborczych i referendalnych. Namysł taki powinien później przyczynić się do wyeliminowania rozwiązań wadliwych i optymalizacji istniejących, przede wszystkim zaś musi stać się punktem wyjścia do planowania kolejnych akcji. Zakres i ciągłość tych prac wymaga, by zajął się nim wyspecjalizowany zespół ludzi, o wysokich kompetencjach analitycznych, wyodrębniony najlepiej jako osobny zespół w strukturze KBW na poziomie centralnym. Taki zespół analityczno-prawny byłby „zasilany" zarówno informacjami, jak i analizami płynącymi z terenu. Oznacza to więc konieczność uwrażliwienia delegatur na sprawy oceny sprawności organizacyjnej i analizy obowiązującego prawa z punktu widzenia praktyki.

Niezależnie od powołania takiego wewnętrznego zespołu, KBW powinno współpracować z różnymi wyspecjalizowanymi instytucjami analitycznymi - zarówno o charakterze państwowym, jak i przede wszystkim naukowo-badawczym - celem ciągłego ewaluowania swojej działalności i wyników. W tym celu powinien zostać powołany stały, roboczy, interdyscyplinarny zespół (lub tematyczne zespoły) przy PKW/KBW, złożony z wysokiej klasy naukowców, zewnętrznych ekspertów znających problematykę prawa wyborczego i referendalnego oraz systemów wyborczych, nowoczesne metody zarządzania i komunikowania, znających praktyczno-organizacyjne uwarunkowania procesów wyborczych w Polsce oraz mających wiedzę informatyczną (przynajmniej na poziomie wizji). Zespół ten pełniłby z jednej strony funkcje doradczo-opinodawcze, a $z$ drugiej analityczno-badawcze na potrzeby PKW/KBW. ${ }^{13}$ Byłaby to rola swego rodzaju zewnętrznego audytora, który zapewniałby niezależne, naukowe i co istotne zewnętrzne spojrzenia na procedury wyborcze. W tym sensie stanowiłby ważne uzupełnienie i wzmocnienie zespołu analitycznego w KBW. Co więcej, mógłby on zajmować się kwestiami i problemami, którymi sama PKW i KBW bezpośrednio się nie zajmują lub zajmować się z powodów politycznych czy organizacyjnych nie chcą, a co do których istnieją społeczne oczekiwania, jak choćby wskazywanie przyszłych kierunków zmian w prawie wyborczym, analiza zjawiska głosów nieważnych, działania w kierunku upowszechniania wiedzy o wyborach i aktywizacji społeczeństwa itd.

13 W tym miejscu należy wspomnieć, że takie zaplecze już w dużej części istnieje w postaci dwóch Centrów Studiów Wyborczych (ośrodki badawcze usytuowane na wydziałach prawa Uniwersytetu Mikołaja Kopernika w Toruniu i Uniwersytetu Łódzkiego). Warto wykorzystać ten potencjał, zwłaszcza że nie wiąże się to z koniecznością ponoszenia dodatkowych nakładów czy wprowadzania zmian w prawie. 
Pomysł powołania podobnej agendy o charakterze badawczo-analityczno-edukacyjnym, jednak jako osobnej instytucji bezpośrednio podległej PKW, nie jest nowy. Już w 2005 r. pojawił się pomysł powołania Państwowego Instytutu Wyborczego. Zgodnie z założeniami tego projektu, PIW miałby być ciałem apolitycznym, stałym, skupiającym ekspertów z dziedziny prawa, politologii, socjologii, psychologii społecznej, pedagogiki i administracji. Posiadałby własną osobowość prawną, jednakże nadzór nad działalnością Instytutu sprawowałaby Państwowa Komisja Wyborcza. Tym samym powstałby sui generis ,trójkąt instytucjonalny”, w ramach którego pod auspicjami PKW działałyby dwa organy: istniejące już Krajowe Biuro Wyborcze (jako organ techniczno-administracyjny) i Państwowy Instytut Wyborczy (jako organ badawczo-edukacyjny). Nowa instytucja prowadziłaby na potrzeby PKW (ale nie tylko) działania konsultacyjne i doradcze, poszerzone o aktywność analityczną, edukacyjną i informacyjną dotyczącą kompleksowych zagadnień wyborczych. ${ }^{14}$

\section{Reforma struktury polskiej administracji wyborczej}

Kolejnym ważnym przejawem opisywanego kryzysu była powolność czy wręcz brak decyzji w obliczu informatycznej awarii. Analizując wypowiedzi członków PKW można było odnieść wrażenie, że nie mają oni pełnej świadomości skali nieprawidłowości i błędów, jakie miały miejsce. W rezultacie uspokajające komunikaty o tym, że „usunięto kolejne błędy” i ,systemowi przywrócono sprawność” nie mogły brzmieć wiarygodnie w sytuacji, w której zaskoczeni takim stanowiskiem PKW, członkowie TKW nadal nie mogli zakończyć procedury weryfikacji i agregacji wyników głosowania z obwodów, a w konsekwencji ustalić wyników wyborów na swoim obszarze i wydrukować właściwych protokołów. ${ }^{15}$ Nie przesądzając w tym miejscu, czy zawinił bardziej wykonawca czy zespół informatyki wyborczej KBW, niewątpliwie odpowiedzialność za tę dezinformację, która tylko pogłębiła rozmiar i czas trwania kryzysu oraz wywoła ogromne straty o charakterze wizerunkowym dla PKW, a szerzej dokonała podkopania społecznego zaufania do aparatu wyborczego i stosowanych w Polsce procedur wyborczych, była wynikiem nieprawidłowego obiegu informacji na linii wykonawca - zespół informatyki wyborczej KBW - delegatury KBW w terenie - kadra kierownicza KBW - członkowie PKW. Bezpo-

Zob. J. Zbieranek, Aktywizacja wyborcza obywateli. Propozycja powołania Państwowego Instytutu Wyborczego, Warszawa 2005. Przed godz. 6.00 dnia 18.11 .2014 r. PKW poinformowała media, powołując się na informacje od wykonawcy
oprogramowania i urzędnika odpowiedzialnego za obsługę informatyczną wyborów w KBW, że: „system informatyczny Państwowej Komisji Wyborczej uzyskał pełną sprawność". Tymczasem w wielu miejscach zamiast całkowicie generować protokoły, system drukował tylko cześćciowo wypełniony szablon, w miejscu gdzie powinien pojawić się gotowy do podpisania dokument. Zob. PKW zapewnia: System działa w pełni; http://www.rmf24.pl/ raport-samorzad-2014/news/news-pkw-zapewnia-system-dziala-w-pelni,nld,1553665\#utm_source=paste\&utm_ medium=paste\&utm_campaign=chrome (data dostępu: 09.01.2015 r.). 
Wnioski i postulaty (nie tylko) de lege ferenda w obliczu kryzysu w wyborach...

średnią odpowiedzialność za ten stan rzeczy ponoszą osoby zarządzające i koordynujące projektem wdrożenia informatycznego.

Fałszywy obraz sytuacji, brak ewaluacji poprzednich akcji i wyciągania wniosków z zauważonych błędów natury organizacyjno-informatycznej, niestosowanie narzędzi nadzoru kierowniczego, nieresponsywność w czasie kryzysu oraz błędna polityka komunikacyjna zarówno wewnętrzna, jak i zewnętrzna, doprowadziły do paraliżu decyzyjnego, a w konsekwencji dymisji całego składu PKW i szefa KBW. Honorowa postawa decydentów nie rozwiązała jednak żadnego z problemów natury systemowej. Analiza kryzysu pokazuje, że zawiodła przede wszystkim organizacja projektu wdrożenia informatycznego oraz obieg informacji wewnątrz KBW. Z tego powodu już w czasie jego trwania niektórzy eksperci wskazywali, że należy oddzielić kompetencje oraz sam charakter takich instytucji, jak PKW i KBW. Ta pierwsza stoi bowiem na straży prawidłowości przebiegu wyborów, podczas gdy druga jest odpowiedzialna za stronę organizacyjną wyborów i to tam popełniono błędy. ${ }^{16}$ Podobne konkluzje sformułowano podczas seminarium eksperckiego zorganizowanego przez Fundację im. Stefana Batorego w Warszawie. ${ }^{17} \mathrm{~W}$ materiale przygotowanym po tym spotkaniu wskazano, że w obecnym stanie prawnym na PKW spoczywa odpowiedzialność za realizację najważniejszych zadań związanych z wyborami, tymczasem zapewnienie warunków organizacyjno-administracyjnych, finansowych i technicznych, związanych z organizacją i przeprowadzaniem wyborów i referendów, to domena KBW. ${ }^{18}$ Biuro pełni więc rolę instytucji obsługującej PKW, ale formalnie nie jest obarczone bezpośrednio odpowiedzialnością za takie kluczowe obszary organizacyjne, jak: zapewnienie oprogramowania informatycznego ${ }^{19}$ czy ustalanie wyników wyborów, nawet jeśli w praktyce koordynuje wszelkie działania z tym związane. ${ }^{20}$

Wydaje się, że w obliczu błędów w procesie decyzyjnym oraz nieskuteczności nadzoru nad KBW przy jednoczesnym obarczeniu odpowiedzialnością prawną PKW za prawidłowość przeprowadzenia wyborów, należy poważnie zastanowić się nad zmianą relacji pomiędzy tymi instytucjami. Byłoby to wręcz niezbędne, gdyby zdecydowano się na powołanie - opisywanego w poprzednim punkcie - Państwowego Instytutu Wyborczego. Wymaga to oczywiście zmiany kodeksowej, wpierw

16 Zob. wypowiedź politolog Anny Materskiej-Sosnowskiej w wywiadzie dla portalu Onet: P. Henzel, Dr MaterskaSosnowska: ruszyła lawina, to największy kryzys od 1989 roku; http://wiadomosci.onet.pl/tylko-w-onecie/dr-materska-sosnowska-ruszyla-lawina-to-najwiekszy-kryzys-od-1989-roku/ec33p (data dostępu: 28.12.2014 r.). Informacje uzyskane dzięki obserwacji uczestniczącej autora w seminarium zorganizowanym przez Fundację im. Stefana Batorego w Warszawie w dniu 8 grudnia 2014 r. pt.: Wybory: wiarygodność $i$ sprawność.

Zob. art. 187 ustawy z dnia 5 stycznia 2011 r. Kodeks wyborczy (Dz.U. z 2011 r. Nr 21, poz. 112 z późn. zm.).

19 Art. $162 \S 2$ kodeksu wyborczego. Obowiązek określenia warunków i sposobów wykorzystania techniki elektronicznej oraz zapewnienia do tego niezbędnego oprogramowania nakłada na PKW.

20 Zob. D. Sześciło, Jakich zmian potrzebuje Państwowa Komisja Wyborcza i Krajowe Biuro Wyborcze?, opracowanie przygotowane w związku z seminarium zorganizowanym przez Fundację im. Stefana Batorego w Warszawie w dniu 8 grudnia 2014 r. pt.: Wybory: wiarygodność $i$ sprawność. 
jednak należy się zastanowić, jaki charakter miałaby uzyskać administracja wyborca w Polsce.

W literaturze przedmiotu wskazuje się wiele klasyfikacji modeli organizacji administracji wyborczej we współczesnych państwach demokratycznych. Wypada jednak zgodzić się z Andrzejem Sokalą, że najbardziej klarowny podział wyróżniony został na podstawie kryterium jej niezależności. W tym sensie wyodrębnić można rządową administrację wyborczą (taki model znaleźć można m.in. w Austrii, Belgii, Czechach, Danii, Niemczech, Szwecji, we Włoszech, Wielkiej Brytanii), administrację całkowicie niezależną od rządu (występuje w Polsce i prawie wszystkich państwach Europy Wschodniej) oraz model mieszany, łączący cechy obydwu (m.in. we Francji, Hiszpanii, Portugalii, na Słowacji, na Węgrzech). ${ }^{21}$ Przyjęty w naszym kraju (oraz w prawie wszystkich państwach o analogicznej historii) model niezależnej administracji wyborczej, w świetle doświadczeń minionej epoki i zrozumiałej w tym kontekście nieufności obywateli do organów państwa, jest zupełnie oczywisty. ${ }^{22} \mathrm{Co}$ więcej, model ten zasadniczo sprawdził się w ciągu ponad 20 ostatnich lat i kryzys związany z jedną elekcją nie powinien tego faktu przesłaniać. Trzeba jasno podkreślić, że sędziowski skład organów wyborczych wyższego szczebla (w tym przede wszystkim PKW) gwarantuje obiektywizm i niezależność od wszelkiego rodzaju nacisków politycznych. W tej sytuacji pomysły, by upolitycznić czy też bardziej „uwrażliwić” skład tych organów na czynniki polityczne należy uznać za krok wstecz. Tym bardziej, że od 2002 r. poziom nieufności Polaków do instytucji politycznych i administracji rządowej jest ciągle wysoki, szczególnie zaś w odniesieniu do partii politycznych. ${ }^{23}$

Nie negując więc założeń samego modelu, można, a miniony kryzys pokazał, że trzeba, zastanowić się nad wadami jego wewnętrznej konstrukcji. Przede wszystkim należy go tak zreformować, aby jasno ulokować odpowiedzialność konkretnych organów za faktycznie wykonywane przez nie zadania oraz uporządkować ścieżkę decyzyjną. W tym celu najpierw powinniśmy zidentyfikować główne kategorie zadań, jakie stoją przed organami wyborczymi, a następnie przypisać je, wraz z kompetencjami i odpowiedzialnością, do odpowiednich struktur mających je później realizować.

Zasadniczo możemy wyodrębnić następujące kategorie zadań: nadzór nad przestrzeganiem prawa wyborczego, organizacja wyborów, audyt wyborów, informacja i edukacja wyborcza, kontrola finansowania polityki. Kwestie związane z organizacją wyborów (w zakres czego wchodzi ich planowanie, realizacja, koordynacja działań innych podmiotów, informatyka wyborcza itp.) powinny być wyłączną domeną Krajowego Biura Wyborczego. Jego szef mógłby być nie tyle organem wykonawczym PKW, co swego rodzaju „władzą wykonawczą” aparatu wyborczego.

23 Zob. A. Cybulska, Zaufanie społeczne, „Komunikat z Badań CBOS” 2012, nr 33, s. 15. 
Wnioski i postulaty (nie tylko) de lege ferenda w obliczu kryzysu w wyborach...

Oznacza to również konieczność rozdzielania funkcji szefa KBW i sekretarza PKW. Zlikwidowałoby to $\mathrm{z}$ jednej strony możliwość nadmiernego uzależnienia czy wręcz zdominowania PKW przez KBW, z drugiej zaś pozwoliłoby Biuru na pełną niezależność (ale też i odpowiedzialność prawną) w zakresie organizacji wyborów. W tym modelu KBW staje się więc osobnym, specjalistycznym aparatem zajmującym się tylko i wyłącznie przygotowaniem i przeprowadzeniem technicznej strony wyborów. PKW zostałaby „odseparowana” instytucjonalnie, choć nie funkcjonalnie od KBW. Jej rola polegałaby na sprawowaniu nadzoru nad przestrzeganiem prawa wyborczego zarówno przez KBW, jak i wszystkie inne organy władzy publicznej, komitety wyborcze, obywateli. Zachowałaby również prawo rozstrzygania sporów oraz dokonywania interpretacji prawa wyborczego. W gestii Komisji powinna znaleźć się również cała materia normotwórcza (uchwalanie wiążących wytycznych, projektowanie i opiniowanie aktów normatywnych związanych $\mathrm{z}$ wyborami i referendami itp.). Mogłaby również pełnić rolę swego rodzaju sądu w sprawach wyborczych i być najwyższą instancją odwoławczą od decyzji komisji wyborczych niższych szczebli, które powinny jej bezpośrednio podlegać. Powinna również być adresatem wszelkich audytów, analiz i kontroli dokonywanych wobec jakichkolwiek organów państwa biorących udział w procesie wyborczym, w szczególności zaś KBW. Na tej podstawie powinna im później przedstawiać swoje rekomendacje i zalecenia na przyszłość. PKW zachowałaby więc swój sędziowski i niezależny charakter oraz obecny tryb kreacji, ewentualnie z wyjątkiem wprowadzenia zasady kadencyjnej rotacyjności członkostwa.

W odniesieniu do pozostałych zadań można wybrać jeden z dwóch wariantów. Powołać osobną instytucję, jak w projekcie przewidującym utworzenie Państwowego Instytutu Wyborczego, o statusie podobnym lub analogicznym do KBW, w którego gestii pozostałyby sprawy z zakresu informacji i edukacji wyborczej. Pełniłby on również rolę specjalistycznego, i co najistotniejsze niezależnego organizacyjnie wobec instytucji kontrolowanych, organu analityczno-audytorskiego dla PKW i KBW, co gwarantowałoby jego wysoki poziom obiektywizmu. Z kolei zadania z zakresu kontroli finansowania polityki powinny zostać wyłączone z obszaru zadań administracji wyborczej i przekazane np. Najwyższej Izbie Kontroli jako właściwemu organowi kontroli prawa, zwłaszcza w zakresie finansów publicznych.

W drugim wariancie, wszystkie powyższe zadania (z ewentualnym przekazaniem nadzoru nad finansowaniem polityki do NIK) pozostałyby w gestii KBW. Oznacza to jednak konieczność radykalnej reorganizacji struktury wewnętrznej, kadrowej i organizacyjnej Biura i powołania nowych zespołów odpowiedzialnych za analizę i audyt (np. zespół analityczno-prawny) oraz informacje i edukację wyborczą (np. zespół informacji wyborczej). Z całą pewnością wszystkich ww. zadań nie mógłby realizować, już w tej chwili przeciążony i niedoetatowany, Zespół Prawny i Organizacji Wyborów KBW. 


\section{Poprawa przejrzystości procesu ustalania wyników głosowania i wyborów}

Utrata sprawności organizacyjnej aparatu wyborczego doprowadziła jednocześnie do podważenia wiarygodności procedur ustalania wyników głosowania i legitymizacji wyborów samorządowych. Pojawiły się głosy, że wynik tych wyborów nie odpowiada rzeczywistości, jest wypaczony, czy ,zafałszowany”, a z trybuny sejmowej padło nawet oskarżenie o jego sfałszowanie. ${ }^{24}$ Zaskoczenie spowodowane dobrym wynikiem Polskiego Stronnictwa Ludowego w wyborach do sejmików województw, medialne zamieszanie związane z broszurowym formatem kart do głosowania i zasadami ważności głosu oraz duża liczba głosów nieważnych, tylko wzmacniały i uprawdopodobniały głosy tych, którzy twierdzili, że wyniki tych wyborów są nierzetelne. Od razu też pojawiły się pomysły, by zwiększyć uprawnienia mężów zaufania, wprowadzić bieżący monitoring elektroniczny pracy OKW, przezroczyste urny wyborcze, alternatywny sposób zliczania głosów itp. Wspólnym mianownikiem tych propozycji było przeświadczenie, że proces ustalania wyników głosowania, a w konsekwencji wyborów, przestał gwarantować ich uczciwość. W zgiełku tej polityczno-medialnej burzy, mało kto zauważył, że zarówno OKW, jak i TKW w Polsce zostały pomyślane jako mechanizm nawet nie społecznej, co par excellence politycznej kontroli uczciwości i rzetelności wyborów. Członkowie OKW rekrutują się bowiem w całości, z wyjątkiem jednej osoby „technicznej” nominowanej przez wójta (a w miastach burmistrza lub prezydenta), z osób zgłoszonych przez startujące w wyborach komitety wyborcze. ${ }^{25}$ Ratio legis takiego rozwiązania nie polegała na tym, jak czasami błędnie się uważa, by dać „ludziom zarobić przy liczeniu głosów", ale by członkowie komisji zgłoszeni przez różne komitety wzajemnie „patrzyli sobie na ręce”, kolegialnie ustalali wyniki głosowania i wspólnie podpisywali protokół stanowiący oficjalne potwierdzenie ustalonych przez nich wyników. Protokół taki musi zresztą, natychmiast po jego sporządzeniu, zostać wywieszony w loku komisji wyborczej w miejscu zapewniającym wyborcom możliwość jego swobodnego odczytania. Zasada społecznego czynnika kontroli na szczeblu OKW jest w Polsce tak silnie ugruntowana, że ustępowały jej, skądinąd zasadne i konsekwentnie co wybory odnawiane w obliczu wielu błędów i nieprawidłowości w działaniach ich członków, postulaty jakiegokolwiek sprofesjonalizowania tych komisji czy też wprowadzenia bardziej merytorycznych kryteriów naboru, jak chociażby cenzus wykształcenia czy wieku.

24 Chodzi o wypowiedź Jarosława Kaczyńskiego z dnia 26 listopada 2014 r. podczas debaty sejmowej nad projektem skrócenia kadencji samorządów: „Z tej najważniejszej w Polsce trybuny muszą paść słowa prawdy: te wybory zostały sfałszowane. Nawet, jeżeli by ktoś nie chciał w to uwierzyć, z różnych względów, to i tak ilość głosów nieważnych, a także to ogromne zamieszanie, które powstało w trakcie liczenia głosów, delegitymizuje te władze, a wartość konstytucyjna demokratycznej legitymizacji władzy jest z całą pewnością wyższa niż wartość konstytucyjna, jaką jest kadencyjność". 
Komisje obwodowe to ważny, ale wcale nie jedyny mechanizm gwarantujący uczciwość, rzetelność i przejrzystość wyborów. Równie istotną, choć w praktyce słabo wykorzystywaną, instytucją tego typu są mężowie zaufania, których do komisji także zgłaszają komitety wyborcze. O ile członkowie OKW nie są formalnymi reprezentantami zgłaszających ich komitetów, o tyle mężowie zaufania ze swej istoty mają pilnować przede wszystkim tego, by głosy ich komitetu zostały policzone prawidłowo. Zarówno jedni, jak i drudzy mają też prawo wnoszenia oficjalnych uwag (skarg, dostrzeżonych nieprawidłowości, wątpliwości itp.) do protokołu komisji. Do tych uwag komisja musi się później ustosunkować, a komisje wyższego szczebla mają obowiązek zbadania, czy w danej sytuacji nie doszło do naruszenia prawa wyborczego. Uwagi takie mają również niebagatelne znaczenie w sytuacji rozpatrywania ewentualnych protestów wyborczych przez sądy, kolejny z ważnych mechanizmów kontroli uczciwości wyborów. W praktyce jednak takie uwagi zgłaszane są rzadko, a już całkowicie sporadycznie wiążą się z poważnymi i uzasadnionymi zarzutami co do uczciwości i rzetelności pracy obwodowych komisji wyborczych.

Kodeks wyborczy - podobnie jak wcześniejsze ordynacje wyborcze - zawiera jak widać niemały i zasadniczo całkowicie wystarczający zestaw mechanizmów zapewniających zarówno uczciwość, jak i przejrzystość w procesie ustalania wyników głosowania i wyborów. To, że w praktyce nie wszystkie te instytucje są właściwie wykorzystywane, bo np. komitety wyborcze nie przywiązują należytej wagi do kwalifikacji tak moralnych, jak i intelektualnych czy organizacyjnych zgłaszanych przez siebie kandydatów na członków OKW i mężów zaufania, nie może obciążać w żaden sposób polskiego systemu wyborczego czy tym bardziej jego aparatu administracyjnego. Trzeba jasno w tym miejscu przypomnieć, że w Polsce wyniki głosowania ustala się nie elektronicznie, tylko robią to ręcznie członkowie obwodowych komisji wyborczych licząc karty do głosowania z zaznaczonymi na nich głosami. Na kolejnych etapach dokonuje się już tylko zsumowania i matematyczno-formalnej weryfikacji ustalonych przez OKW danych. Jakiekolwiek ewentualne fałszerstwa czy nieprawidłowości w ustalaniu wyników są możliwe na etapie identyfikacji i liczenia głosów ważnych, co zgodnie z prawem powinni robić wspólnie i komisyjnie wszyscy członkowie OKW. Niestety, w praktyce jest to nakaz nierzadko łamany. Dodajmy też, że najczęściej z powodów czysto organizacyjnych. Nie ma więc uzasadnionych merytorycznie powodów, by twierdzić, że proces ustalania czy ogłaszania wyników był nieprzejrzysty czy sprzyjał manipulacjom. To, że oficjalne, podkreślmy, zbiorcze wyniki w skali kraju zostały podane przez PKW tydzień po wyborach, nie może być jakimkolwiek uzasadnieniem dla twierdzeń, że były one fałszowane. Ponad 27 tys. OKW w całym kraju ustaliły i podały do publicznej wiadomości (wywieszając w swoim lokalu stosowne protokoły) wyniki głosowania w swoich obwodach w noc powyborczą, bądź najpóźniej w poniedziałek 17 listopada 2014 r. Trudności i opóźnienia pojawiły się, jak to już zostało wyżej wskazane, na etapie weryfikacji i agregacji tych danych na szczeblu TKW, które z tego powodu nie mogły przez kilka dni 
wytworzyć swoich własnych protokołów. Problem z ewentualną nieprzejrzystością dotyczy zatem nie samego procesu ustalania wyników głosowania, ale co najwyżej szybkości i formy ich publicznego ogłaszania. Tutaj też należałoby szukać potencjalnych błędów i możliwych do zastosowania usprawnień.

Nie może bowiem podlegać żadnej dyskusji to, że kluczowym czynnikiem wpływającym na poczucie uczciwości i przejrzystość w procesie ustalania wyniku wyborów jest szybkość podania ich do wiadomości publicznej, dodajmy na szczeblu masowym, bo tylko na tym poziomie mieliśmy do czynienia z opóźnieniem. Co zatem zrobić, by to poczucie przywrócić? Jakie można podjąć kroki, by dodatkowo jeszcze poprawić przejrzystość tego procesu? Z całą pewnością nie zapewni tego, postulowane na fali ostatniego kryzysu przez coraz więcej osób, wprowadzenie przejrzystych urn na karty do głosowania. Nie rozwiązuje to bowiem żadnego z podniesionych problemów, nie chroni przed ewentualną próbą fałszerstw ze strony członków komisji, a tworzy tylko dodatkowe problemy techniczne związane z koniecznością zabezpieczenia wrzuconych do urny kart przed możliwością ujawnienia głosu wyborcy.

Pierwszym mechanizmem, który już istnieje, ale jak już wskazano powyżej nie jest właściwie wykorzystywany i z tego powodu należałoby się poważnie zastanowić nad jego gruntowną reformą, jest instytucja mężów zaufania. Powinien się on stać kluczowym elementem kontroli społecznej prawidłowości i przejrzystości wyborów na wszystkich jego etapach, przede wszystkim zaś na etapie przeprowadzania, ustalania i publikowania wyników głosowania i wyborów. By tak się stało instytucja ta powinna zostać zmodyfikowana $\mathrm{z}$ realizującej obecnie funkcję męża zaufania poszczególnych komitetów wyborczych do funkcji krajowego obserwatora wyborczego. W tym celu poszerzeniu powinien ulec katalog podmiotów uprawnianych do zgłaszania takich obserwatorów o organizacje pozarządowe mające w swoim statucie jako cel działania, ogólnie rzecz biorąc, rozwój lub monitorowanie stanu demokracji w Polsce itp. Dodatkowo także o badaczy afiliowanych przy krajowych jednostkach organizacyjnych o charakterze naukowym. Rzetelność i warsztat naukowy tych drugich gwarantować będą nie tylko wnikliwość obserwacji, ale również właściwą ewaluację i wnioski. W kolejnym kroku warto pomyśleć również o wytworzeniu narządzi dla takich obserwatorów w postaci instrukcji, poradników, sugestii na co zwracać szczególną uwagę, list kontrolnych, kalkulatorów wyborczych, a może nawet specjalnych szkoleń, warsztatów, dzięki czemu ich obserwacja mogłaby być $\mathrm{z}$ jednej strony lepsza jakościowo, a z drugiej łatwiejsza dla samych obserwujących. Ich opracowaniem mógłby zająć się np. specjalny zespół ds. informacyjno-edukacyjnych KBW lub instytucja na wzór Państwowego Instytutu Wyborczego. Relacje, sprawozdania, raporty z takich obserwacji byłyby nie tylko formą społecznej kontroli uczciwości i rzetelności wyborów, ale miałyby również duże znaczenie w procesie ewaluacji sprawności organizacyjnej komisji wyborczych. 
Drugim kluczowym obszarem jest szybkość nie tyle ustalania wyników (ta zależy bowiem z jednej strony od sprawności członków komisji, a z drugiej obsługującego ich systemu informatycznego), co ich upubliczniania. W sytuacji, w której wspomaganie informatyczne wyborów jest od 10 już lat wykorzystywane na szczeblu obwodu, a protokół z głosowania jest niczym innym jak wydrukiem ze stosowanego przez OKW ,kalkulatora wyborczego", z funkcjonalnego punktu widzenia doszło do odwrócenia relacji pomiędzy tym co jest oryginałem i tym co jest jego pochodną. Obecnie protokół papierowy, który jest oficjalnym dokumentem z wyborów i musi być wytworzony przez komisje wszystkich szczebli, jest tylko komputerowym wydrukiem obrazującym stan bazy danych agregujących wyniki głosowania po jego zakończeniu na danym szczeblu (obwodu, okręgu, jednostki terytorialnej, całego państwa). Nie ma zatem żadnych merytorycznych, ani technicznych przeciwwskazań, aby to „elektroniczna wersja protokołu” (a w zasadzie właściwy zestaw danych liczbowych i innych kluczowych informacji autoryzowanych przez zasilającą system informatyczny tymi danymi OKW, a zweryfikowany i zatwierdzony przez komisję wyższego szczebla) stała się oficjalnym, tyle że elektronicznym, odpowiednio zabezpieczonym przed modyfikacją, dokumentem z wyborów. Protokół papierowy stałby się z kolei formalnie tym, czym faktycznie jest już od dawna: papierowym dokumentem archiwalnym, stanowiącym wtórnik, czy też swego rodzaju odpis właściwego dokumentu źródłowego, jakim byłby protokół elektroniczny. W konsekwencji dane elektroniczne zaraz po ich sporządzeniu, w czasie rzeczywistym, mogłyby być publikowane on-line za pośrednictwem specjalnego systemu wizualizacji wyborów zintegrowanego z systemem wspomagania komisji wyborczych. Dla zachowania pełnej przejrzystości tego procesu, wszystkie ewentualne zmiany, korekty czy błędy wychwycone już po jego sporządzeniu przez OKW lub w procesie weryfikacji przez TKW, byłyby w tej wizualizacji zawarte z podaniem godziny, podmiotu i przyczyny modyfikacji, tak jak zazwyczaj podaje się takie informacje $\mathrm{w}$ wielokrotnie edytowanych dokumentach elektronicznych. Zrewolucjonizowałoby to proces publikowania wyników wyborów i wprowadziło maksymalnie możliwą, na masową skalę, przejrzystość procesu ustalania wyników i dostępu do nich z każdego miejsca i na każdym etapie, bez żadnego obciążania komisji wyborczych i tworzenia nowych mechanizmów informatycznych. Wystarczyłoby tylko poszerzyć i zmodyfikować funkcjonalności rozwiązań stosowanych w przeszłości.

Trzecim obszarem jest rozważenie wprowadzenia do polskiego prawa wyborczego możliwości oddania przez wyborcę świadomego i jednoznacznego głosu nie tyle „oficjalnie” nieważnego, bo przez jego prawne zalegalizowanie staje się on przecież jak najbardziej ważny, co „przeciwko wszystkim” lub „na żadnego z powyższych" kandydatów w wyborach do organów kolegialnych. Instytucja ta w literaturze przedmiotu nosi nazwę NOTA. ${ }^{26}$ Niezależnie od stosowanej terminologii, 
główną zasadą jest w tym przypadku danie wyborcy możliwości uchylenia się w sposób sankcjonowany przez prawo wyborcze od wyboru spośród propozycji zawartych na karcie do głosowania. ${ }^{27}$ Nie rozstrzygając w tym miejscu kontrowersji jakie ten, bądź co bądź, negatywny system głosowania budzi, ${ }^{28}$ trzeba zauważyć, że w polskich warunkach jego wprowadzenie rozwiązałoby niezwykle istotny problem z punktu widzenia przejrzystości procesu ustalanie wyników głosowania, zwłaszcza w odniesieniu do wyborów samorządowych: interpretacji skąd się biorą tak duże różnice w liczbie głosów nieważnych w zależności od rodzaju elekcji? W połączeniu z liberalizacją warunków ważności głosu polegającą np. na uznaniu, jako wyraźnego aktu woli wyborcy, znaków innych niż tylko „x” (np. tzw. „ptaszków”, podkreśleń, zaznaczeń lub innych oczywistych w interpretacji znaków graficznych pozwalających jednoznacznie przypisać głos do konkretnej opcji), mogłoby to w konsekwencji doprowadzić do absolutnego zmarginalizowania lub faktycznego wyeliminowania głosów nieważnych.

Co bardziej istotne, NOTA stworzyłaby systemowe rozwiązanie problemu tzw. głosów białych, czyli takich kart, na których wyborca nie postawił żadnego znaku, co otwiera teoretycznie możliwość do ewentualnego fałszowania wyników przez późniejsze dopisywanie znaków „x” na takich pustych kartach. Jej wprowadzenie poszerzałoby zakres możliwych do wyartykułowania w toku wyborów preferencji politycznych obywateli, mogłoby również stanowić ważny impuls ,projakościowy” dla zgłaszających konkretnych kandydatów komitetów wyborczych oraz zmniejszyłoby presję do głosowania strategicznego, czyli niezgodnego ze swoim układem pierwszych preferencji. Mogłoby także przyczynić się do wzrostu frekwencji wyborczej przez zachęcenie do szczerego głosowania osób niezdecydowanych czy kontestujących scenę polityczną, a do tej pory uciekających w absencję wyborczą, głosujących strategicznie, na ugrupowania protestu, czy oddających głosy formalnie nieważne.

\section{Postulaty (nie tylko) de lege ferenda}

Kryzys, jaki ujawnił się w toku wyborów samorządowych 2014 r. był spowodowany przede wszystkim błędami nie o charakterze prawnym, ale zarządczym. W szczególności popełniono błędy na etapie planowania i wdrażania projektu wspomagania informatycznego, nie przeprowadzono właściwej analizy ryzyk, nie przygotowano planu alternatywnego, termin realizacji przedsięwzięcia był za krótki a harmonogram nierealny, w rezultacie zbrakło czasu na testy i audyt oprogramowa-

27 M. Waszak, Możliwość wskazania „żadnego z powyższych” na karcie wyborczej - na przekór logice demokratycznego głosowania, Warszawa 2012, s. 5.

28 Szarzej na temat tej techniki, jej zalet i wad zob. M. Waszak, op. cit.; B. Michalak, Żaden z powyższych, (w:) A. Sokala, B. Michalak, P. Uziębło, Leksykon prawa wyborczego i referendalnego oraz systemów wyborczych, Warszawa 2013, s. 289-291. 
nia. W trakcie realizacji projektu nie dokonywano jego bieżącej ewaluacji i nie korygowano planu nawet wtedy, kiedy było już wiadomo ponad wszelką wątpliwość, że system nie zadziała tak jak powinien. Zawiódł nadzór, komunikacja wewnątrz organizacji i z otoczeniem, zabrakło umiejętności zarządzania kryzysowego. Oznacza to, że i rozwiązania należy szukać raczej w sferze organizacyjno-zarządczej niż prawnej. Biorąc jednak pod uwagę zakres i skutki (również społeczne) ujawnionej, w obliczu kryzysu, niesprawności administracji wyborczej, koniecznie wydaje się poważne rozważenie szeregu zmian kodeksowych, które jednak powinny być nakierowane na to, co faktycznie kryzys wywołało, jak również na to, co może stać się systemowym impulsem przeciwdziałającym podobnym sytuacjom w przyszłości.

Biorąc powyższe zastrzeżenia i wnioski pod uwagę, można sformułować następujące rekomendacje dla podmiotów decydujących o kształcie polskiego modelu wyborczego:

1) należy przeprowadzić pełny, profesjonalny i niezależny audyt zarówno procedur wyborczych, jak i instytucji je stosujących (przegląd prawa wyborczego, stosowanych procedur organizacyjnych, identyfikacja procesów i zadań realizowanych przez administrację wyborczą, zasobów informatycznych i organizacyjnych KBW itp.), mógłby się tym zająć niezależny zespół ekspercki działający na zlecenie PKW;

2) wytworzyć instytucjonalne mechanizmy prowadzenia stałej i bieżącej ewaluacji działań aparatu wyborczego, a na tej podstawie oprzeć planowanie przyszłych akcji wyborczych, formułować rekomendacje prawne i organizacyjne, których celem byłoby eliminowanie błędów i nieprawidłowości oraz ciągła optymalizacja procesów wyborczych;

3) przeprowadzić funkcjonalnie zorientowaną, rzeczową i przemyślaną, nieprowadzącą jednak do utraty ,pamięci systemowej”, ale konsekwentną reorganizację wewnętrzną administracji wyborczej (schemat organizacyjny, stanowiska pracy, kadry) poprzedzoną gruntowną analizą zadań i procesów realizowanych przez Biuro, która doprowadzić powinna do:

a) ponownego określenia charakteru relacji, odpowiedzialności, podziału zadań i kompetencji oraz podporządkowania między PKW i KBW;

b) odciążenia Zespołu Prawnego i Organizacji Wyborów od wszystkich obowiązków z wyjątkiem przygotowania i przeprowadzenia technicznej i organizacyjnej strony wyborów;

c) powołania roboczego zespołu zadaniowego - złożonego z pracowników centrali KBW, informatyków terenowych i zewnętrznych ekspertów - zajmującego się wdrażaniem, zarządzaniem i koordynowaniem projektami informatycznymi;

d) powołania w strukturze KBW zespołu analityczno-prawnego, który przejąłby od ZPiOW zadania związane z obsługa prawną wyborów (przygotowywanie wytycznych, wyjaśnień i innych aktów prawnych) 
a jednocześnie prowadziłby ciągłą działalność o charakterze analityczno-audytorskim na potrzeby organów wyborczych;

e) powołania zespołu informacyjno-edukacyjnego, który zająłby się kwestiami informowania o wyborach, prowadzeniem wszelkiego rodzaju wewnętrznych szkoleń wyborczych, aktywizowaniem wyborców oraz polityką komunikacyjną organów wyborczych;

f) (alternatywie względem powyższych) rozdzielenia zadań i funkcji nadzorczych, organizacyjnych i analityczno-informacyjnych pomiędzy trzy, ściśle ze sobą współpracujące, ale organizacyjnie niezależne instytucje: PKW, KBW i PIW;

4) przekształcić nieefektywną instytucję mężów zaufania reprezentujących interesy komitetów wyborczych w społecznych obserwatorów krajowych zgłaszanych przez szerszy krąg podmiotów, ustanawiając tym samym realny mechanizm społecznej kontroli wyborów;

5) zalegalizować dane wprowadzane przez OKW do systemu informatycznego jako oficjalną, elektroniczną i pierwotną wersję protokołu głosownia oraz umożliwić masowy dostęp do tych danych w czasie rzeczywistym;

6) wprowadzić kategorię głosu świadomie nieważnego, przez umieszczenie na karcie do głosowania pozycji ,głosuję na żadnego z powyższych kandydatów" (ang. NOTA) i jednoczesną liberalizację warunków ważności głosu.

\section{BIBLIOGRAFIA}

Cybulska A., Zaufanie społeczne, „Komunikat z Badań CBOS”2012, nr 33

Feliksiak M., Opinie o działalności parlament, prezydenta i PKW, „Komunikat z Badań CBOS” 2014, nr 16

Griffin R.W, Podstawy zarządzania organizacjami, wyd. 2, Warszawa 2004

Michalak B., Żaden z powyższych, (w:) A. Sokala, B. Michalak, P. Uziębło, Leksykon prawa wyborczego i referendalnego oraz systemów wyborczych, Warszawa 2013

Sokala A., Administracja wyborcza w obowiązującym prawie polakiem, Toruń 2010

Sześciło D., Jakich zmian potrzebuje Państwowa Komisja Wyborcza i Krajowe Biuro Wyborcze?, Robocze opracowanie przygotowane $\mathrm{w}$ związku z seminarium zorganizowanym przez Fundację im. Stefana Batorego w Warszawie w dniu 8 grudnia 2014 r.

Waszak M., Możliwość wskazania ,żadnego z powyższych” na karcie wyborczej - na przekór logice demokratycznego głosowania, Warszawa 2012

Zbieranek J., Aktywizacja wyborcza obywateli. Propozycja powołania Państwowego Instytutu Wyborczego, Warszawa 2005 
Wnioski i postulaty (nie tylko) de lege ferenda w obliczu kryzysu w wyborach...

\section{CONCLUSIONS AND RECOMMENDATIONS (NOT ONLY) DE LEGE FERENDA AFTER THE CRISIS \\ IN THE POLISH LOCAL ELECTIONS OF 2014}

The last local elections in Poland took place on 16th November 2014. The election ended in crisis due to collapse of the electronic system supporting the election. In this article the author claims that the crisis did not happen because of bad electoral law but rather as a result of bad management of the electoral process. The Polish electoral administration needs several reforms. First is a necessary reorganisation of the National Election Office. Second is the evaluation of all procedures, laws and processes concerning organization of elections in Poland. Third, the electronic voting protocol should be given priority.

Keywords: local election in Poland, electoral code, electoral administration, Polish National Electoral Commission and National Election Office

Słowa kluczowe: kodeks wyborczy, administracja wyborcza, organizacja wyborów, Państwowa Komisja Wyborcza, Krajowe Biuro Wyborcze 